\title{
Study on Confucianism's Educational Ideology under the Language Competitive Program
}

\author{
Qiaoling Chen ${ }^{1, \text { a }}$, Quanxiang Zhao ${ }^{2, b}$ \\ ${ }^{12}$ Shaanxi University of Science \& Technology, Xi'an, Shaanxi, 710021
}

Keywords: Confucianism; Example Teaching; Language Competition Program

\begin{abstract}
It is an important part of the traditional Confucian thought and it is an important part of ideological and political education. The current society is complicated and changeable, and Confucianism's example education has suffered a series of challenges, and it is imperative to think about the development path of Confucianism. The new language athletics program provides an opportunity for our thinking.
\end{abstract}

\section{Introduction}

Chinese culture has a long history and a long history. In this river of Chinese culture, Confucianism's example of education has always been an important tributary. Thousands of years of Confucianism example of the idea of education, continuous development and improvement, that is still shining now. Modern society provides a new platform for the development of Confucian model education, but it also highlights some of its problems. This article will contact the modern example of the new way of education - language competition programs, the role of thinking about some of the thinking.

\section{The Characteristics of Confucianism}

Confucianism, the example of education, has undergone three stages of development. The first is the development stage, mainly refers to the early enlightenment thought, Jia Yi and Dong Zhongshu's enlightenment thought and the enlightenment thought of the Tang Dynasty; finally, the development of the Confucianism, Stage, this stage is mainly concentrated in the Song, Yuan, Ming and Qing Dynasties, such as Kangxi's "to teach first" thinking. In these three stages, the Confucian model of educational thought has its own characteristics, but according to the dialectical relationship between personality and commonality, they also have some common ground, mainly:

Historical materialism holds that social existence determines social consciousness, social consciousness is a reflection of the existence of society, Confucianism as a social consciousness, reflect the inevitable interests of the ruling class and demand. In fact, at all times, the views of the various thinkers on the example of education are reflected in the role of education for the purpose of political service. For example, "Shangshu Yao Dian" mentioned in the "Keming Junde, to pro-nine; nine family harmony, ordinary people; people Zhaoming, Concorde million, Li people in the variable when Yong", refers to only the virtues of education, In order to make the family intimate and harmonious, in order to identify the good and evil of the Baiguan, in order to reconcile the princes of harmony, and ultimately achieve the purpose of political stability. Another example is Confucius, advocating "ancestor Yao and Shun, charity", to the ancient emperor as a model to transform the society, in order to achieve its highest political ideals - Datong society. [1] after the Mencius, in the "benevolence" on the basis of "good governance, not as good as the people of the people also. Good and evil fear, good people love, good governance was good people, good teach people", is also reflected in the education of And the role of political stability, he believes that the example of education as an important part of education and methods, must be dependent on the political lips and teeth, for the monarch, only their body is in order to return to the world. In the Western Han Dynasty, Dong Zhongshu, the representative of the Confucian school, elaborated the relationship between the example teaching and social politics according to the actual situation of the Han Dynasty society. He believes that "Seoul good friendship, the people to the benevolent and 
vulgar; Seoul good profit, the people are evil and vulgar. From the concept of the emperor's husband, the people of the visual effect, the distance between the four Also. "He also believes that" where the education is not established and the people are not also. "The people of the people from the benefit also, such as the water to go, not to teach the embankment, can not stop." Thus, the Confucian example of the purpose of enlightenment Is to maintain the rule of the ruling class.

Confucianism is closely related to the discussion of human nature. It can be said that the theory of human nature is the foundation of Confucianism. Confucianism that "everyone can be Yao and Shun" point of view, indicating that there is no difference in human innate character, saints in the acquired education gradually developed. The specific view of Confucianism about human nature is not consistent. First of all, Confucius put forward the "similarity, Xi Xiangyuan", Mr. Yang Bojun explained: "human nature is similar, because the different dyeing, they are far apart." [2] that human nature is similar, but because of learning And other factors are far behind [3]. After Mencius adhere to the point of view of human nature, he believes that human nature is a benevolent virtue, that "compassion, everyone has; shame evil heart, everyone has; respectful heart, everyone has; And Xunzi is adhering to the concept of human nature of evil, he also suggested that if people do not have ethical ethics or statute will become evil, such as "good people who teach that good And the people who said Shun; to poor ancestors that flatter, to the poor and people who flatter. "Han Dynasty Dong Zhongshu focused on the" people of the sex ", he compared it to eggs and cocoon, that" The egg is to be dying for twenty days and then for the young, the cocoon to be used for the soup and then for the silk, sex to be gradually after the lesson and then can be good. "But, regardless of the ancestors uphold what kind of human point of view, they agree that people Between the saints and mortals between the same nature, so mortals can learn from the example of the saints, and ultimately become a saint. It is worth mentioning that the Confucian model of the assumption of human nature assumptions, denied the differences between people, is not conducive to the overall development of people, but also makes the effect of education greatly reduced. However, it must be recognized that the generalized human nature hypothesis provides the possibility for the implementation of Confucianism.

Confucianism's example teaching attaches great importance to "speech" and "teaching". First of all, the Confucian example of education is very important "words and deeds". "Chuan Chuan" refers to the role of education through the language, mainly refers to the school education. Whether it is Confucius's "emperor lost his official, learning in the four Yi" can test the private school, or to the Han Dynasty to build a smooth system of official system, have made a large-scale example of education possible, so Confucianism attaches great importance to classroom teaching. "Torture" refers to the example of enlightenment through physical practice. Confucianism example of the idea of education that the value of the people as well as the spirit of social fashion, depends entirely on the rulers, so the saints kings must be personally exemplary. Confucius said, "his body is, not to do so; his body is not correct, though not from." Zhu Xi's reference to Fan's interpretation: "not yet positive and can be", its intention to explain the rulers of their own repair Driving and role models. [4]. Mencius that "no way not to his wife," meaning to walk in the community must own first road, otherwise it is difficult to achieve the education of society, which is the recognition of the body. Lao Tzu and Chuang Tzu's "do not teach the words" "do not teach" that the main body of moral education to lead by example, establish a good example, so that educators have moral revelation, to achieve the purpose of physical education is also important to teach. Confucianism is the example of education in the school to instill the example of teaching two kinds of educational methods based on the realization of the unity of knowledge and practice, to ensure the effectiveness of the example of education.

\section{The Confucian Model of the Lack of Ideology}

Confucianism's example of educational thought, in the development process has formed a number of valuable ideas, for example, it advocates the practice of the example of education, and, for example, it proposed to establish the emperor's wise minister's positive example and transgressive courtiers of the negative typical. However, according to the Marxist philosophy is divided into two 
view of the problem, the Confucian example of the idea of education must also be some deficiencies. The following will explain these shortcomings:

Wang Qiaohua in her book "Introduction to Model Education" will be the example of education elements summarized as an example, educators and educators three, the Confucian model of the idea of its elements also include these three. So what is the subject of the Confucian example? Han Yu has taught the pedigree as shell, Shun, Yu, Tang, Wen, Wu, Zhou Gong, Mencius, and Zhu Xi will Shao Yong, Zhou Dunyi, Zhang Zai, two brothers as a new preacher of the preacher. Despite the different views, but through summary found that they are usually virtuous and won the history and people recognized the saints king. In fact, in the eyes of Confucianism, only the book of saints, with a gentleman cultivation, noble character and the world's feelings of the gentleman scholar, in order to play the responsibility of enlightenment. Confucius had in the "Ziyi" in the relationship between the king and the people than the relationship between the heart and the body, and to explain the importance of the saints prince virtuous, he said, "heart is the body Shu, heart Su is respectful, heart good The king of the words and deeds of the "king of words and deeds will be" the king is not benevolent, so the minister of corruption and evil, and not for the letter of faithful to report on the monarch and herd, was in the world, And the world of the people can not be their own life. "[5] Therefore, the king must be the behavior of learning to follow the example and model. This kind of enlightenment of the subject, clear the requirements of the instructor, regulate the behavior of the saints king, but also inevitably led to the education of the main body of the singular, elite, idealized. And lead to dampen the public enthusiasm, poor education and a series of problems. The so-called gold is not enough red, no perfect people, saints, although the king is the example of the main body of education, but they said that good conduct can not always be revealed, and even be tempted to evil, then, the sage king for the people to do the example is Negative of the negative, so the Confucian will be raised on the sage king self-cultivation requirements. Thus, the sage king as the main body of education is the Confucian example of a lack of education.

Although the main body of Confucianism is the sage of the sage, but because of its goal is to guide the ordinary people to the good, to encourage people to become virtuous people, so the content of education is mainly benevolence, justice, reason, wisdom, Will be to a certain extent with the moral determinism of the color. As early as the Zhou Dynasty, Zhou Gong put forward the idea of "with Germany with heaven", although this idea is to solve the cause of the destruction of the Shang Dynasty and the "days" turned to Zhou Wang reason, or in order to make the rule of the Zhou Dynasty The But in fact, "with Germany with the day" thinking is the "moral", rather than "days." At the same time in his advocacy of "morality" point of view, the ultimate goal of punishment is to persuade the people to be good, so that virtue. In Confucius' whole thought system, "benevolence" and "ritual" are two very important aspects. He advocated benevolent love and self-promulgation, in fact, is to start from the moral to bind people's actions, so that the ceremony. Mencius advocated "benevolence", starting from "benevolence", in the ruling method, he attached importance to the role of moral role. He believes that "within the father and son, outside the monarch and the minister, the people of the big Lun also", if "no justice, then up and down chaos." After that, Jia Yi that the ceremony is feudal hierarchy rules and moral norms, is the ruler of the country at the root of the fundamental, Dong Zhongshu advocate virtue and moral education, two way to talk about justice, benevolence. These are enlightened from the example of morality. The moral-oriented example of education, the impact may be small, from a personal point of view will inevitably ignore the development of other aspects of the country, from the country, will underestimate the development of economic science and technology. Therefore, the moral-oriented content of education there is a certain irrationality.

As mentioned above, Confucianism is taught for the ruling class, which is the social function or political function of Confucianism. In general, the role of model education includes individual functions and social functions. [6] The individual function of the model education refers to the positive function of the example for the social individual, including the incentive function, the control function, the adjustment function and the correction function. The social function of example education refers to the example of social governance techniques. In modern society, we 
can understand this function as an example education is an indispensable content of the construction of socialist spiritual civilization, on the feudal society is to understand the role of education on the monarchical system of monarchy, is a political service function The The traditional Confucian model of education, around the "inner saints outside the king," the enlightenment of the road, in the governance of the country, focusing on emphasizing the role of the role of the government, the example of governance in the world of emperor, royal family and officials of the doctor group, which means The majority of the people will never be qualified to become the main body of education, thus eliminating the people want to become the main body of the consciousness of education, leading to self-improvement in the people do not take the initiative, not work, which means that the example of education to enhance the individual quality is ruler For the template, which will lead to similar imitation never been beyond the phenomenon of the occurrence of personal perfection can only be within the scope of the monarch to allow the perfect, these are not real individual development. In fact, the example of teaching to achieve the individual function, must be able to arouse the individual's altruistic behavior, arouse individual morale; must be able to consciously control their own behavior does not meet the example; must be able to reconstruct their own role under the influence of example; But also must be able to make people often use the deeds of advanced figures against their own words and deeds, to overcome shortcomings to correct their own bad behavior. Obviously, the traditional example of education in this piece is lacking.

\section{The Enlightenment of Language Competitive Class on the Confucianism}

The ideology of the new Confucianism has played a great role in history, because "most human behavior is obtained through observation of the example" [7]. However, any kind of ideology is only with the times and social history, can be timeless. Confucianism's example of thinking to continue to play a role in thinking, it is inevitable to make a change. The following will be from the perspective of language competition program for the Confucian example of education to make some comments:

Confucianism, like the example of the idea of the sage of the saints as the main body of education, greatly affirmed the sage king of the people's livelihood and regulate the role of words and deeds. However, the relationship between things is generally linked to the sage king as the main example of education also produced a certain negative impact, such as the example of the main elite of the idealized, the lack of examples of age and life and so on. In fact, China is now gradually becoming the backbone of society after the number of people reached 220 million, [8] the traditional Confucian example of education can not even meet the needs of this major group. The language competition program is a new program that expresses a life experience or a successful experience by means of speech. It has a special theme, the form of novel and other characteristics, is to shape the image of example, to convey the spirit of example of inspirational programs. The language athletic class has a variety of age and various industries, there are successful people, there are ordinary people. For example, celebrity-based "talk" program, both sports stars Jun River, Feng Shao, there are popular singer Xiao Jingteng, as well as scientists Yang Zhenning and performing artist Qin Yi. Which the youngest 23 years old, the oldest has been 93 years old. And "I am a speaker" is basically follow the lineup, guests are from ordinary people. This kind of guest composition, reflecting the aspirations of the public, the player type diversity, first meet the people on the example of the diverse needs, no matter wherever they can, you can choose the appropriate reference example; Second, to avoid the example of the elite and idealized, The sage king as an example, will result in a certain degree of mountain up the situation, so that people can not reach the lineup, close to the people, close to life, easier for the people to accept, to achieve the mortal pass; Finally, The main body of the traditional Confucian model, although the moral and other education on the contemporary have a positive meaning, but the contemporary society, the people need more to help them better survival and development of the example, such as entrepreneurs, such as network People, obviously, the language of sports programs better reflect the needs of the people of this era. In summary, the Confucian model of education in the selection of example to the modernization of life to diversify closer to achieve mutual benefit. 
Although the traditional Confucian model of education and education of the main body is for the saints and other social superiors, but its goal has always been to guide the general public to the people, so that people become virtuous people. Therefore, both through the "my day and three provinces I," the way of inspection, or the way of classroom teaching, Confucianism, the content of education has always been around the moral. The moral content of virtue is conducive to political stability, social harmony and personal character promotion, but it will also weaken the development of other countries and individuals. At present, the speakers involved in science and technology, education, literature, literature, politics and other fields and actors, singers and other occupations, their own occupation characteristics, industry knowledge will be reflected in the speech, virtually rich The content of the enlightenment; second, different levels of speakers, both in the field of success, such as the director Feng Xiaogang, a singer Jay Chou, but there are ordinary people in life, and even people with disabilities, such as blind female Dong Lina and sitting Lin Yu-hsin in the wheelchair, their different life experiences and life insights, is an important role in the teaching of nourishment; there is, the guests of the theme is very rich, both on the family's thinking, such as "clouds behind the happiness line", also On the dream of thinking, such as "Do not put the dream on the road", there is an analysis of the marriage on love, such as "a kind of love to life and death." Overall, the theme of the country involved in the world of moral and intellectual aspects of the United States, which is the traditional Confucian example of education can not match. In fact, people in the process of watching the program, from their actual situation, choose their own situation in line with their own example, these examples or self-confidence, or perseverance, or moral, or academic rigor, or between or indirectly, Greatly enhance the various aspects of the people of education, and these in line with the mainstream values of the country's educational content, the role of the community also. Thus, it is essential to enrich the content of Confucianism.

Confucianism, in the way of enlightenment, is mainly the traditional indoctrination of the way of enlightenment, as Lenin said, "no one's feelings, it is impossible to pursue the truth." [9] This way of education is not conducive to the Lord The emotional communication between the object is not conducive to improving the participation of the people, but also is not conducive to the realization of enlightenment effect. Now the language competition program in accordance with the "ideological and political propaganda work to enhance the relevance, effectiveness and attractiveness" [10] requirements, the public generally accepted the way of television programs, through the example of the way to promote the example of example, enhanced Model example of the image of vivid, better cause the resonance of the soul, effectively enhance the appeal of the example of education. At the same time, the language competition program focuses on the participation of the people, first, the guests choose the audience to vote mainly for the election of CCTV programs, as well as the audience themselves to participate in the form of competition, so that people themselves involved, which is conducive to enhancing the people on the example The second, pay attention to communication with the public, in the language of sports programs, usually with mentor questions, questions and other aspects of the audience, to achieve the audience and example guests close communication, deepen the understanding of the example, is conducive to Combined with the example of the answer to local conditions to solve some of their own problems; third, the use of network tools to guide the participation of all. This is mainly reflected in three aspects, namely the creation of special sites, set up special forums and open microblogging. This is conducive to expanding the scope of publicity, but also conducive to the network name and example of the interaction, so that education from the classroom, from the TV to the network, which is a major breakthrough in the way of education. In fact, both the CCTV talk show program, or Beijing TV is my speaker, have the official microblogging and specialized sites, and these programs will be associated with the heat and influence. Therefore, the traditional Confucian model of education can take this as a mirror to achieve a great change in the way of enlightenment.

As an important method of ideological and political education, Confucianism plays an important role in ideological and political education. But things are constantly changing development, Confucianism, the example of the idea of education must be constantly changing with the times to introduce new, to be timeless. Each of the major TV language sports programs dare to break the 
traditional example of education, in the selection of examples, publicity and other aspects of a breakthrough, is the traditional example of education to achieve sustainable development of a medicine, transmission of Confucianism in the class of education in its guidelines , Will be able to a higher level.

\section{References}

[1] Yuan Wenbin. Ancient Chinese model education theory and its contemporary enlightenment [J]. Hebei Journal, 2010 (1): 136-139

[2] Yang Bojun. Analects of Confucius Notes. [M]. Beijing: Zhonghua Book Company, 181

[3] Li Chenggui. Confucian model of education and its contemporary province [J] Qilu Journal, 2014 (4): 5-11

[4] Zhu Xi. Four books set of Notes [M]. Beijing: Zhonghua Book Company, 2011: 130.

[5] Ye Shi set [M]. Beijing: Zhonghua Book Company, 1961: 747

[6] He Di II. Example education difficulties and way out [J] Journal of Shandong Youth Institute of Politics, 2011 (1): 81-84.

[7] [US] A - Bandura (Lin Ying translation). The Social Basis of Thought and Behavior - Social Cognition (Volume 1) [M]. Shanghai: East China Normal University Press, 2001: 63.

[8] Li Chunling. Circumstances, attitudes and social transformation: 80 after the young sociology research [M] Beijing: Social Science Literature Publishing House, 2013: 57

[9] Lenin. Lenin Complete Works [M]. Beijing: People's Publishing House, 1958: 225

[10] The CPC Central Committee. Guan ten to strengthen and improve the ideological and political work methods and opinions [N], 1999-09-29 